\title{
EVALUATION OF ANTI-Schistosoma mansoni IgG ANTIBODIES IN PATIENTS WITH CHRONIC SCHISTOSOMIASIS MANSONI BEFORE AND AFTER SPECIFIC TREATMENT
}

\author{
Célia Maria V. VENDRAME(1), Márcia Dias T. CARVAlHO(2), Célia Regina F. YAMAMOTO(3), Maria Cristina NAKHLE(1), Silvino Alves CARVALHO(1)
}

\& Pedro Paulo CHIEFFI(1,4)

\begin{abstract}
SUMMARY
The circumoval precipitin test (COPT), enzyme-linked immunosorbent assay (ELISA) and the immunoblotting anti-adult worm antigen (AWA) and soluble egg antigen (SEA) tests were applied to 17 chronically schistosome-infected patients for the detection of anti-Schistosoma mansoni antibodies before and on four occasions after oxamniquine administration over a period of six months. Compared to a control group, schistosomiasis patients showed high levels of IgG antibodies in AWA and SEA-ELISA. A decrease in IgG levels was observed six months after treatment, although negative reactions were not obtained. Significant decreases in IgG $\mathrm{IgG}_{3}$ and, mainly, $\mathrm{IgG}_{4}$, but not anti-SEA $\mathrm{IgG}_{2}$ levels were observed six months after treatment, again without negativity. Analysis of anti-AWA IgG antibodies by immunoblotting before treatment showed a $31 \mathrm{kDa}$ strand in 14 patients $(82 \%)$ which disappeared in three cases up to six months after treatment; furthermore, anti-SEA IgG antibodies showed the same band in nine patients (53\%) before treatment, which disappeared in only four cases up to six months after treatment.
\end{abstract}

KEYWORDS: Schistosomiasis diagnosis; Schistosomiasis cure evaluation; Immunenzymatic tests; Immunoblotting.

\section{INTRODUCTION}

In Brazil there are at least 2,500,000 individuals infected with Schistosoma mansoni and about 25 millions live in areas where the transmission of this helminthiasis may be possible ${ }^{32}$. The laboratory diagnosis of active schistosomiasis mansoni is made principally by the finding of $S$. mansoni eggs in the stool ${ }^{9}$. However, fecal parasitologic tests are not considered to have high sensitivity because of factors such as irregularity in Schistosoma egg shedding ${ }^{3,8}$, absence of egg laying just after anti-schistosome treatment even if not successful and tissue egg retaining due to intestinal fibrosis ${ }^{29}$. Thus, several immunological tests using crude or purified egg and adult worm antigens have been developed in the last decades to detect anti-S. mansoni antibodies and some of them have been proposed for treatment evaluation.

The circumoval precipitin test (COPT) is one of the exams used for the diagnosis of schistosomiasis and for the evaluation of antischistosome treatment ${ }^{31}$ and consists of immune complex formation around schistosome eggs incubated with serum from schistosomeinfected individuals. It is considered as a highly sensitive and specific test and usually becomes non-reactive from 6 to 12 months after antischistosome treatment ${ }^{14,33}$. However, in some instances, patients continue to have positive COPT results after specific anti-schistosome treatment or test negativity occurs only a long time after treatment ${ }^{16}$.
Immunoenzymatic tests for anti-S. mansoni antibodies utilize antigens obtained from either adult worms or eggs. Some of these tests show a decrease in anti-schistosome antibody levels soon after specific treatment ${ }^{34}$, while others show the persistence of high antibody levels up to 18 months $^{10}$. When IgG subclasses are analyzed there is a decrease in all subclasses, with special relevance in the case of $\mathrm{IgG}_{4}{ }^{2}$.

Immunoblotting tests have been used to detect AWA antibodies since an immunogenic fraction with a molecular weight of $31-32 \mathrm{kDa}(\mathrm{Sm}$ 31/32) was considered to be the most frequently recognized fraction and could therefore be used as a serologic marker ${ }^{35,36,43}$. Furthermore this fraction became negative or decreased in the serum of treated patients exposed to a low infection risk $^{35,36}$. On the other hand, KIMURA ${ }^{22}$ did not obtain the same results.

Using the immunoblotting test for SEA, NOYA et al..$^{30}$ studied a group of patients after therapy and identified a special fraction of about $31 \mathrm{kDa}$ which decreased after specific treatment. This fraction, corresponding to the Omega 1 antigen described by DUNNE et al. ${ }^{7}$, was present in a special schistosome egg antigen known as cation exchanging fraction-6 (CEF-6) and has been considered an important diagnostic marker for cure control. Moreover, this antigen is one subcomponent of COPT and has been considered as a very sensitive and specific antigen $^{5,27,28}$. DOENHOFF et al. ${ }^{4}$, employing this antigen as a serologic

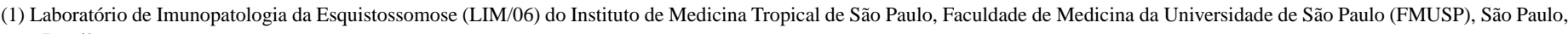
Brasil.

(2) Laboratório de Lípides (LIM/10) do Instituto de Medicina Tropical de São Paulo, FMUSP, São Paulo, Brasil.

(3) Laboratório de Imunologia (LIM/48), do Instituto de Medicina Tropical de São Paulo, FMUSP, São Paulo, Brasil.

(4) Faculdade de Ciências Medicas da Santa Casa de São Paulo, São Paulo, Brasil.

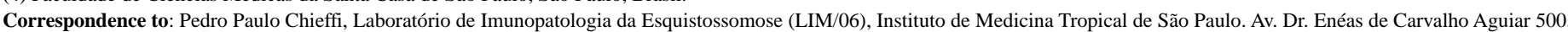
$2^{\circ}$ andar, 05403-000 São Paulo, SP, Brasil. Fone/Fax: +55-11-3064-5132. E-mail: pchieffi@ usp.br 


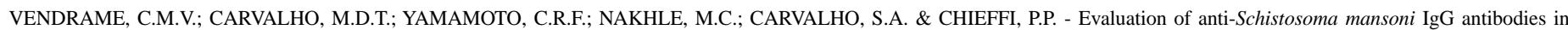
patients with chronic schistosomiasis mansoni before and after specific treatment. Rev. Inst. Med. trop. S. Paulo, 43(3):153-159, 2001.

marker, observed $50 \%$ and $80 \%$ negative reactions in schistosomiasis patients from Santa Lucia, West Indies, six and 12 months after treatment, respectively. However, a similar evaluation of patients from Puerto Rico did not show the same results ${ }^{6,15}$.

The occurrence of controversial results when the same immunological technique is used in different populations justifies the evaluation of tests usually employed in the diagnosis and cure control of schistosomiasis under our operational conditions in order to standardize immunological evaluation of schistosomiasis treatment. Furthermore, the decrease of the rate of infection with $S$. mansoni in Brazil, particularly in São Paulo State, strengthens the importance of using an immunological technique of diagnosis rather than parasitological tests in epidemiological surveys.

\section{MATERIAL AND METHODS}

Patients and sera: After informed consent, 17 chronically schistosome-infected male and female patients ranging in age from 17 to 77 years (mean age $=33$ ), with either the intestinal or hepatointestinal form of the disease were studied. All of them were migrants from different Brazilian endemic areas for schistosomiasis, living in São Paulo City and admitted to the Hospital das Clínicas, Universidade de São Paulo. During the study they did not return to endemic areas. Blood and fecal samples were taken immediately before and 40, 90, 150 and 180 days after treatment with oxamniquine $(15 \mathrm{mg} / \mathrm{kg}$ weight). Blood was allowed to clot at room temperature and centrifuged and serum was separated and kept frozen at $-20{ }^{\circ} \mathrm{C}$ until testing. Diagnosis of schistosomiasis mansoni before and after treatment was performed by the Kato-Katz method $^{21}$, with three microscope slides prepared for each sample. Control sera were obtained from 30 Brazilian blood donor volunteers.

Adult worm antigen (AWA) preparation: Adult S. mansoni worms (BH strain) were collected by portal perfusion of infected hamsters with $0.9 \%$ sodium chloride solution. Worms were thoroughly washed with PBS and stored at $-20^{\circ} \mathrm{C}$. Approximately 12,000 adult male and female worms were thawed, homogenized in saline with $1 \mathrm{mM}$ phenylmetylsulfonyl fluoride (PMSF), disrupted by hand and homogenized with a Potter-Elvehjem apparatus for 1 hour at $4{ }^{\circ} \mathrm{C}$. They were then centrifuged at $26,000 \mathrm{x}$ g for 1 hour at $4{ }^{\circ} \mathrm{C}$ using an SW 41 rotor (L-8 ultracentrifuge, Beckman Instruments Inc, Palo Alto, CA, USA).

Soluble egg antigen (SEA) preparation: S. mansoni eggs were isolated from liver and intestinal walls of infected hamsters by differential sieving and washed by repeated centrifugation. SEA was prepared as described by BOROS \& WARREN ${ }^{1}$.

The protein contents of AWA and SEA were determined by the method of LOWRY et al. ${ }^{25}$ using bovine albumin as standard, lyophilized in small aliquots and stored at $-70^{\circ} \mathrm{C}$.

Circumoval precipitin test (COPT): This method was performed as previously described by OLIVER-GONZÁLEZ ${ }^{31}$. S. mansoni eggs obtained as above were adjusted to a concentration of 50 eggs $/ 10 \mu \mathrm{L}$ in hypertonic solution, added to $25 \mu \mathrm{L}$ of patient serum and incubated at $37^{\circ} \mathrm{C}$ for 48 hours. The reaction was read under the light microscope according to the criteria described by SPENCER et al. ${ }^{40}$, i.e. $<10 \%$ of eggs with circumoval precipitation indicated in a negative reaction and $>/=10 \%$ a positive reaction.

Enzyme-linked immunosorbent assay (ELISA): Polystyrene microtiter plates (Costar, Cambridge, MA, USA) were coated with 50 $\mu \mathrm{L}$ of either AWA or SEA at a protein concentration of $10 \mu \mathrm{L} / \mathrm{mL}$ diluted in PBS supplemented with 0.05 Tween 20 (PBS-T), kept for 2 hours at $37{ }^{\circ} \mathrm{C}$ and then for 16 hours at $4{ }^{\circ} \mathrm{C}$. Between the steps of the reaction wells were washed three times with $200 \mu \mathrm{L}$ of PBS-T for 1 hour at room temperature. Then $50 \mu \mathrm{L}$ of diluted serum (1:200) were added to the wells and incubated for 1 hour at $37{ }^{\circ} \mathrm{C}$; after this time $50 \mu \mathrm{L}$ of horseradish peroxidase goat anti-human IgG (SIGMA, Chemical Co., St. Louis, MO, USA; IgG 1:5,000 for AWA and SEA) were added. After incubation for 1 hour at $37{ }^{\circ} \mathrm{C}, 50 \mu \mathrm{L}$ of substrate solution were added and 15 minutes after incubation at room temperature the enzymatic reaction was stopped by the addition of $50 \mu \mathrm{L}$ of $4 \mathrm{~N} \mathrm{H}_{2} \mathrm{SO}_{4}$. Absorbance was read at $492 \mathrm{~nm}$ in a Titertek Multiskan MCC/340P, model 2.20 (Labsystems, Finland) and the results were obtained by duplicate readings. Optimal dilutions of the antigen protein concentration for coating the wells and serum and conjugate dilutions were determined previously by checkerboard titration using pooled positive and negative sera. An optical density (OD) greater than the mean plus two standard deviations of the value for 30 healthy Brazilian individuals was considered to be the cut-off point.

ELISA for the anti-SEA IgG subclass: This test was performed with sera obtained before and 180 days after anti-S. mansoni treatment. IgG subclass antibodies were detected using a slightly different protocol: $50 \mu \mathrm{L}$ of serum samples were diluted 1:200 in PBS-Tg and incubated for 16 hours at $37{ }^{\circ} \mathrm{C}$. Mouse monoclonal antibodies specific for each

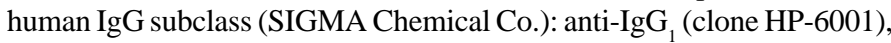
anti-IgG ${ }_{2}$ (clone HP-6014), anti $\mathrm{IgG}_{3}$ (clone HP-6050) and $\mathrm{IgG}_{4}$ (clone HP-6025) were used at 1:1,000 in blocking buffer. Thereafter, $50 \mu \mathrm{L}$ of peroxidase-conjugated sheep anti-mouse Ig (SIGMA Chemical Co.) at 1:1,000 dilution in blocking buffer were added for 1 hour at $37{ }^{\circ} \mathrm{C}$. Subsequently the protocol was performed as previously described.

Immunoblotting: Proteins were separated electrophoretically under reducing conditions by one-dimensional SDS-PAGE as described by LAEMMLI $^{24}$. AWA $(215 \mu \mathrm{g})$ and SEA $(225 \mu \mathrm{g})$ were boiled for 3 minutes and applied to the $10 \%$ polyacrylamide gel using a Mini Protean II apparatus (Bio-Rad Labs, Hercules, CA, USA). High range molecular weight standards were also obtained from Bio-Rad Labs.

The separated proteins were electrotransferred to NCP using a Trans Blot transfer cell apparatus (Bio-Rad Labs) and $4 \mathrm{~mm}$ strips were cut. Non-specific sites were blocked with $0.05 \%$ Tween 20 supplemented with 5\% non-fat dry milk in PBS adjusted to $\mathrm{pH} 7.4$ (PBS-Tm). Serum diluted at 1:100 in PBS-Tg was added and kept for 1 hour at $37{ }^{\circ} \mathrm{C}$. After washing in PBS-T, the enzymatic conjugate labeled with alkaline phosphatase for human anti-IgG at a previously determined optimal dilution was added and incubated for 2 hours at $37^{\circ} \mathrm{C}$. Then, after another washing, blots were visualized with the enzymatic substrate bromo-cloroindolyl-phosphate and nitroblue tetrazolium in $1 \mathrm{M}$ Tris (BCIP-NBT) with $4 \mathrm{M}$ sodium chloride, $\mathrm{pH} 9.5$.

The reaction was stopped by washing the strips in distilled water. The strips showing protein recognition by the schistosomiasis patient 
sera were scanned using an optical densitometer and measured by analysis of one-dimensional separation and dot blots using an Image Master Program 1.20 produced by Pharmacia Biotech AB.

Statistical analysis: The results are expressed as mean and standard deviation. The ANOVA test with the Student Newman-Keuls contrast post-test was used for statistical analysis of the various groups. The paired and unpaired Student test and Pearson correlation were used for statistical comparison of two groups. A level of confidence of $95 \%$ ( $p<0.05)$ was considered as significant.

\section{RESULTS}

This study was carried out on 17 patients with a parasitological diagnosis of schistosomiasis mansoni made by the Kato-Katz method. Ninety days after treatment with oxamniquine (a single oral dose of 15 $\mathrm{mg} / \mathrm{kg}$ weight) all patients yielded negative results in fecal exams; the COPT, on the other hand, remained positive in one case (Table 1).

Table 1

Circumoval precipitin test (COPT) applied to 17 chronic schistosomiasis patients before and after specific treatment

\begin{tabular}{cccccc}
\hline & & & & \multicolumn{2}{c}{ COPT } \\
\cline { 5 - 6 } Patients & Clinical & Age & Fecal eggs/g & Before & 180 days after \\
& Form* & (year) & of feces $\nabla$ & treatment \# & treatment \# \\
\hline 1 & I & 34 & 96 & + & - \\
2 & I & 27 & 192 & + & - \\
3 & I & 39 & 2304 & - & - \\
4 & I & 32 & 1344 & + & - \\
5 & I & 29 & 24 & + & - \\
6 & I & 31 & 96 & - & - \\
7 & I & 32 & 24 & + & - \\
8 & I & 26 & 288 & - & - \\
9 & HI & 31 & 120 & + & - \\
10 & HI & 41 & 96 & + & - \\
11 & I & 42 & 24 & - & - \\
12 & I & 37 & 96 & ND & ND \\
13 & I & 21 & 432 & + & + \\
14 & I & 17 & 2472 & + & - \\
15 & I & 28 & 240 & + & - \\
16 & I & 26 & 24 & - & - \\
17 & HI & 77 & 672 & + & - \\
\hline
\end{tabular}

$\mathrm{ND}=$ not determined; $*$ - Clinical form: hepatointestinal (HI) or intestinal (I); $\nabla$ - Counting fecal egg excretion before oxamniquine treatment by the Kato-Katz method $^{21}$. The result is reported as the mean for three slides; \# - Positive reaction $(+) \geq 10 \%$ of immunoprecipitin around viable eggs.

The immunoenzymatic tests (ELISA) performed with antigens obtained from either adult worms (AWA) or S. mansoni eggs (SEA) did not show negative results up to 180 days after treatment. When AWA was used an increase in antibody levels was observed 40 days after treatment, followed by a significant decrease 140 days later, i.e. 180 days after treatment (Fig. 1). Anti-SEA IgG levels were significantly decreased from 90 to 180 days after treatment (Fig. 2).

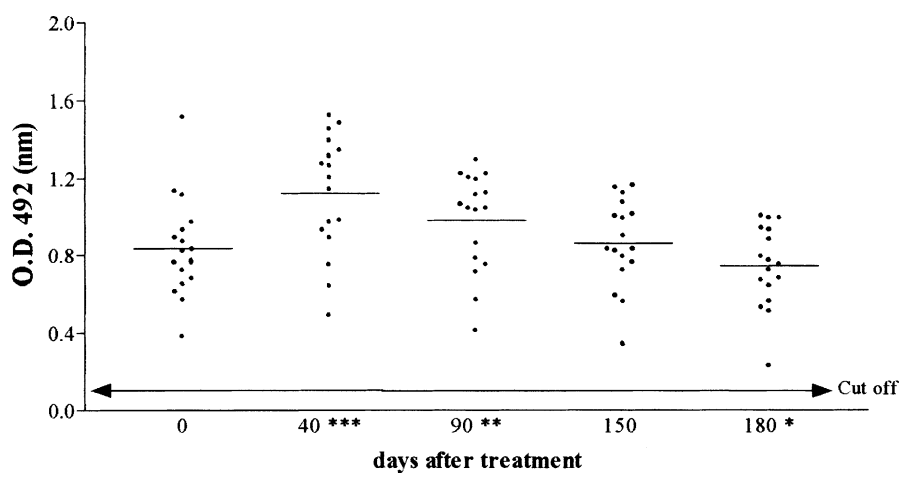

Fig. 1 - Anti-AWA IgG antibodies detected by ELISA in 17 chronic schistosomiasis patients before and after specific treatment. Cut off $=0.173$. ANOVA test with $p<0.0001$ followed by the Student Newman-Keuls contrast post-test with $* * * \mathrm{p}<0.001$, ** $\mathrm{p}<0.01$ and $* \mathrm{p}<$ 0.05 in relation to pre-treatment. Horizontal bar represents the mean value.

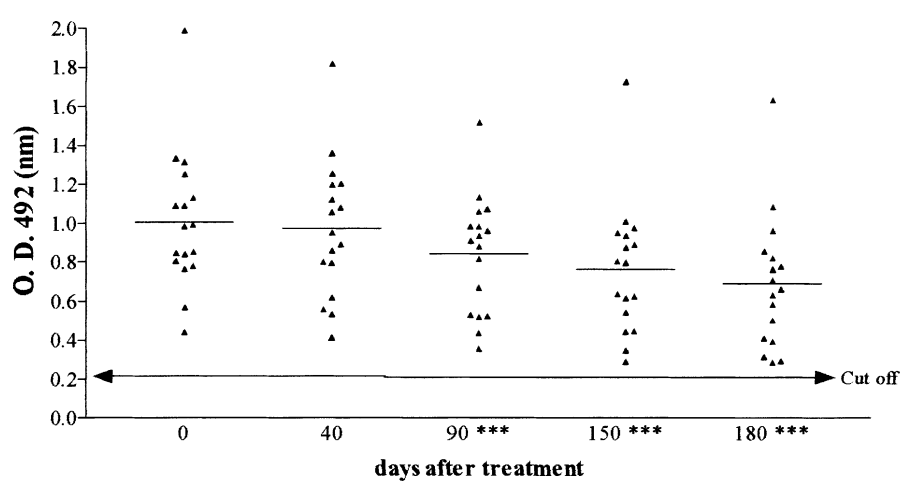

Fig. 2 - Anti-SEA IgG antibodies detected by ELISA in 17 chronic schistosomiasis patients before and after specific treatment. Cut off $=0.208$. ANOVA test with $p<0.0001$ followed by the Student Newman-Keuls contrast post-test with $* * * p<0.001$ in relation to pre-treatment. Horizontal bar represents the mean value.

The anti-SEA $\operatorname{IgG}_{1}, \operatorname{IgG}_{2}, \operatorname{IgG}_{3}$ and $\mathrm{IgG}_{4}$ subclasses were determined and significant decreases in $\mathrm{IgG}_{1}, \mathrm{IgG}_{3}$ and $\mathrm{IgG}_{4}$ levels but not in $\mathrm{IgG}_{2}$ were observed (Fig. 3). $\mathrm{IgG}_{4}$ showed the most significant decrease 180 days after treatment, although the results were still positive.

A heterogenous pattern of reactivity was observed when the immunoblotting for anti-AWA and SEA IgG antibodies of all 17 patients were analyzed before and after 180 days after treatment (Tables 2 and 3). Table 4 shows the percentage of positive bands found in all patients before and 180 days after treatment with oxamniquine.

\section{DISCUSSION}

In the present study, 17 schistosomiasis patients, 14 of them harboring moderate or low parasite burdens, living for several years in a nonendemic area for $S$. mansoni infection were examined before and after treatment with oxamniquine. All of them had been considered cured by fecal tests and all but one by COPT in the evaluation carried out six months after treatment (Table 1). In contrast to reports by others ${ }^{14,31,33}$, under our operational conditions COPT showed a relatively low 

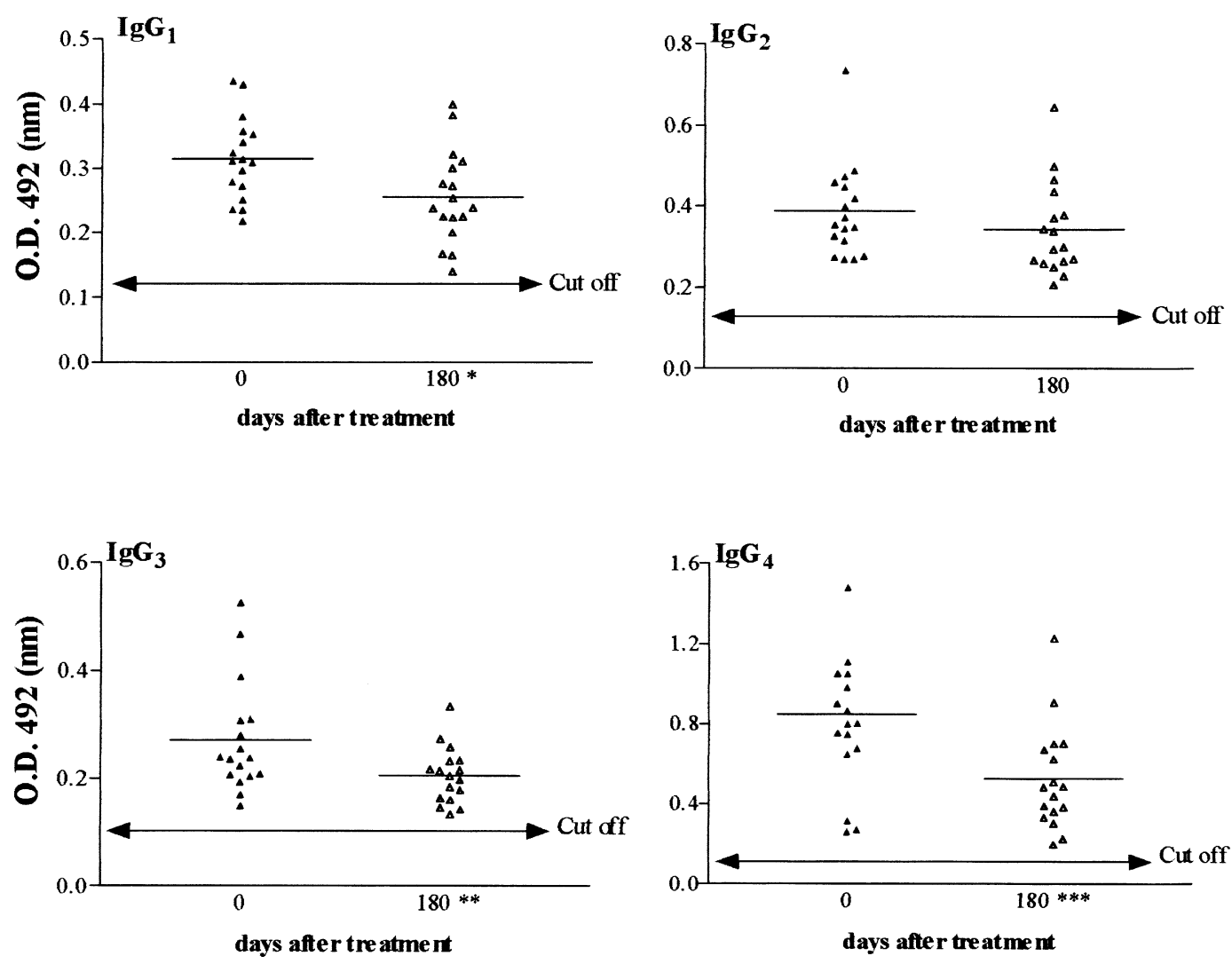

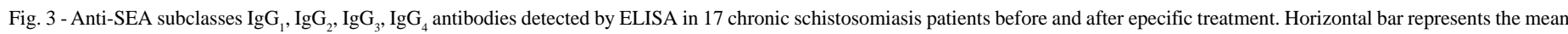
value. Cut off $\left(\mathrm{IgG}_{1}=0.135, \mathrm{IgG}_{2}=0.175, \mathrm{IgG}_{3}=0.121, \mathrm{IgG}_{4}=0.152\right)$. Paired Student $\mathrm{t}$ test with $* \mathrm{p}<0.01$, ** $\mathrm{p}<0.05$, ***p $<0.0001$ in relation to pre-treatment.

Table 2

Antigenic bands reacting with IgG AWA found in chronic schistosomiasis patients

\begin{tabular}{|c|c|c|c|c|c|c|c|c|c|c|c|c|c|c|c|c|c|}
\hline \multirow[b]{2}{*}{$\mathrm{KDa}$} & \multicolumn{17}{|c|}{17 chronically schistosome-infected patients } \\
\hline & 1 & 2 & 3 & 4 & 5 & 6 & 7 & 8 & 9 & 10 & 11 & 12 & 13 & 14 & 15 & 16 & 17 \\
\hline 204 & & & $x \times$ & & $x \times$ & & & & & & & & & $x \times$ & & & \\
\hline 194 & $x \times$ & & $\times \neg$ & & $x \times$ & & & $x \times$ & & $x \times$ & & & $x \times$ & $x \times$ & & $x \times$ & \\
\hline 164 & $x x$ & & $x x$ & $x \times$ & $\neg x$ & & & $x x$ & $x \times$ & $x x$ & $x \times$ & $x \times$ & $x x$ & $x x$ & & $x x$ & \\
\hline 152 & & & & $x x$ & $x \times$ & & & & $x \times$ & $x x$ & $x x$ & $x x$ & & $x x$ & & $x x$ & \\
\hline 130 & $x x$ & & $x x$ & $x x$ & $x x$ & & & $x \times$ & $x x$ & $x x$ & $x x$ & $x x$ & $x x$ & $x x$ & & $x x$ & \\
\hline 115 & $x x$ & & & $x x$ & & & & & $x x$ & $x x$ & $x x$ & $x x$ & $x x$ & $x x$ & & $x x$ & \\
\hline 92 & $x x$ & $x x$ & $x \times$ & $x x$ & $x \times$ & $x x$ & & $x \times$ & $x x$ & $x x$ & $x x$ & $x x$ & $x x$ & $x x$ & & $x x$ & $x x$ \\
\hline 67 & $x x$ & $x x$ & $\times \neg$ & $x x$ & $x x$ & $x x$ & & $x x$ & $x x$ & $x x$ & $x x$ & $x x$ & $x x$ & $x x$ & $x \times$ & & \\
\hline 55 & $x x$ & $x x$ & $\times \neg$ & $\times \neg$ & $x x$ & $x x$ & & $x x$ & $\times \neg$ & & $x x$ & $x x$ & & $x x$ & $\times \neg$ & $x x$ & $x x$ \\
\hline 50 & $x x$ & $x x$ & $x x$ & $x x$ & $x x$ & $x x$ & & $x x$ & רᄀ & & $x x$ & $x x$ & $x x$ & $x x$ & $x x$ & & $x x$ \\
\hline 40 & $x x$ & $x x$ & & & & & & & רר & & $x x$ & $x x$ & & ᄀ & & & \\
\hline 36 & $x x$ & $x x$ & רᄀ & $\times \neg$ & $\neg x$ & & & & & & $x x$ & $x x$ & $x x$ & $\times \neg$ & & & \\
\hline 31 & $x x$ & $x x$ & & $x x$ & $\times \neg$ & $x x$ & $x x$ & & $x \times$ & $\times \neg$ & $x x$ & $x x$ & & ㄱ & $x \times$ & $\neg x$ & $x x$ \\
\hline 25 & & & $\times \neg$ & $x x$ & $\times \neg$ & & & & $x x$ & $\times \neg$ & & $x x$ & & $x x$ & & רר & $x x$ \\
\hline 22 & & & & & $x x$ & & & & & רר & $x \times$ & $x x$ & & & & & \\
\hline
\end{tabular}

The symbols in sequence correspond to the immunoblot reaction for each patient before and 180 days after specific treatment: $(x)$ reacting band and $(\neg)$ non-reacting band. 


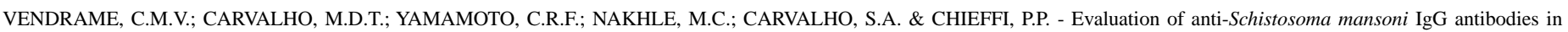
patients with chronic schistosomiasis mansoni before and after specific treatment. Rev. Inst. Med. trop. S. Paulo, 43(3):153-159, 2001.

Table 3

Antigenic bands reacting with IgG SEA found in chronic schistosomiasis patients

\begin{tabular}{|c|c|c|c|c|c|c|c|c|c|c|c|c|c|c|c|c|c|}
\hline \multirow[b]{2}{*}{$\mathrm{KDa}$} & \multicolumn{17}{|c|}{17 chronically schistosome-infected patients } \\
\hline & 1 & 2 & 3 & 4 & 5 & 6 & 7 & 8 & 9 & 10 & 11 & 12 & 13 & 14 & 15 & 16 & 17 \\
\hline 203 & & & $x x$ & & & & & & & & & & & & & & \\
\hline 172 & & & & & & $x x$ & $x x$ & & & $x x$ & $x x$ & $x x$ & $x x$ & & & $x x$ & $x x$ \\
\hline 130 & $x x$ & & & & & $\times \neg$ & & & & $x \times$ & & $\times \neg$ & & & & $x \times$ & $x \times$ \\
\hline 110 & $x \times$ & & $x x$ & & & $\times \neg$ & & & & & & & & & & & \\
\hline 92 & & & & $\times \neg$ & & $x \times$ & & $x \times$ & $x \times$ & & $x \times$ & $x \times$ & $x \times$ & & & $x \times$ & \\
\hline 73 & × & & & & $x x$ & & & & & $x x$ & $\times \neg$ & & & & & & $x x$ \\
\hline 62 & & $x \times$ & $x x$ & $x x$ & $x x$ & & & $x \times$ & $x \times$ & $x x$ & $x \times$ & $x x$ & $x x$ & $x \times$ & & $x x$ & $x \times$ \\
\hline 55 & & $x x$ & $x x$ & $x x$ & $x x$ & & $x \times$ & $x x$ & & $x x$ & $x x$ & $x x$ & $x x$ & $x x$ & & & $x \times$ \\
\hline 50 & × & $x x$ & & $x \times$ & $x x$ & $x x$ & & & & $x x$ & $x x$ & $x x$ & $x x$ & & & $x x$ & $x x$ \\
\hline 41 & $x x$ & & & & $x x$ & & $x x$ & & $\times \neg$ & $\times \neg$ & $x x$ & & $x x$ & $x x$ & $x x$ & $x x$ & $x x$ \\
\hline 37 & & & $x x$ & & $x x$ & $x x$ & $\times \neg$ & & $\times \neg$ & & $x x$ & $\times \neg$ & & & & $x x$ & \\
\hline 31 & $\times \neg$ & & $x x$ & & $x x$ & & & & & $\times \neg$ & $x x$ & $x x$ & $x x$ & & & $\times \neg$ & $x \times$ \\
\hline 25 & $x x$ & & & $x x$ & $\times \neg$ & & & & & $\times \neg$ & $x x$ & $x x$ & $\times \neg$ & & $x x$ & & \\
\hline 22 & & & & $x x$ & $x x$ & $x x$ & $x x$ & & $\times \neg$ & & $x x$ & $x x$ & $x x$ & & & $x x$ & $\times \neg$ \\
\hline 18 & & & & & & & $x x$ & & & $x x$ & $x x$ & & $x x$ & & & $x x$ & \\
\hline
\end{tabular}

The symbols in sequence correspond to the immunoblot reaction for each patient before and 180 days after specific treatment: $(x)$ reacting band and $(\neg)$ nonreacting band.

Table 4

Percent (\%) of anti-AWA IgG and anti-SEA IgG protein bands $(\mathrm{kDa})$ in 17 chronically schistosome-infected patients before and after specific treatment

\begin{tabular}{rccccc}
\hline & \multicolumn{2}{c}{$\begin{array}{c}\text { Anti-AWA } \\
\text { \% reactive patients }\end{array}$} & & \multicolumn{2}{c}{$\begin{array}{c}\text { Anti-SEA } \\
\text { \% reactive patients }\end{array}$} \\
\cline { 2 - 3 } \cline { 5 - 6 } & $\begin{array}{c}\text { before } \\
\text { treatment }\end{array}$ & $\begin{array}{c}180 \text { days after } \\
\text { treatment }\end{array}$ & & $\begin{array}{c}\text { before } \\
\text { treatment }\end{array}$ & $\begin{array}{c}180 \text { days after } \\
\text { treatment }\end{array}$ \\
\hline 204 & 18 & 18 & & 06 & 06 \\
194 & 47 & 41 & & 47 & 47 \\
164 & 71 & 71 & & 35 & 23 \\
152 & 47 & 47 & & 18 & 12 \\
130 & 71 & 71 & & 47 & 41 \\
115 & 53 & 53 & & 29 & 18 \\
92 & 88 & 88 & & 76 & 76 \\
67 & 82 & 76 & & 71 & 71 \\
55 & 82 & 59 & & 65 & 59 \\
50 & 82 & 76 & & 65 & 53 \\
40 & 35 & 23 & & 47 & 29 \\
36 & 53 & 35 & & 53 & 35 \\
31 & 82 & 65 & & 47 & 29 \\
25 & 53 & 29 & & 59 & 47 \\
22 & 23 & 18 & & 29 & 29 \\
\hline
\end{tabular}

sensitivity before treatment. Of 16 patients submitted to this diagnostic procedure only $11(68.7 \%)$ yielded positive results.

The results of immunological tests (anti-AWA and anti-SEA IgGELISA) performed before specific treatment were similar to those obtained by others ${ }^{13,26,28,40}$ and support the usefulness of these techniques for schistosomiasis diagnosis, mainly in areas where the parasite burden is low and consequently fecal tests are less sensitive ${ }^{20}$.
Forty-days after treatment with oxamniquine anti-AWA IgG-ELISA, but not anti-SEA IgG-ELISA antibodies showed a significant increase (Fig. 1) probably as a consequence of antigen release following worm death ${ }^{34,39}$. Up to six months after oxamniquine treatment both anti-AWA and anti-SEA IgG antibody levels showed a significant decrease (Fig. 1 and 2), although not reaching the level of non-infected controls.

As also observed by others, the levels of $\operatorname{IgG}_{1}, \operatorname{IgG}_{2}, \operatorname{IgG}_{3}$ and principally $\mathrm{IgG}_{4}$ anti-SEA antibodies were significantly higher than those found in non-infected people before oxamniquine treatment ${ }^{2,18,19}$ (Fig. 3). Six months after oxamniquine administration a sharp decrease in $\mathrm{IgG}_{4}$ levels and a less significant decrease in $\mathrm{IgG}_{1}$ and $\mathrm{IgG}_{3}$ levels were observed. These results are in agreement with the assumption of best performance of schistosome egg antigens in the evaluation of specific schistosomiasis treatment, as already pointed out by other investigators ${ }^{6,30,42}$.

Positive anti-schistosome serological reactions in patients submitted to efficient specific treatment could be explained either by the persistence of some living worms, without oviposition, in the host's portal system ${ }^{44}$ or by the temporary persistence of schistosome antigens in host tissues ${ }^{12,41}$.

In the 17 patients studied here both anti-AWA and anti-SEA antibody tests resulted positive at least up to six months after oxamniquine administration, indicating that these immunological tests cannot be used for treatment evaluation. However, the greatest decrease in $\mathrm{IgG}_{4}$ levels verified six months after treatment (Fig. 3) deserves attention. This immunoglobulin subclass has been considered as a relatively good marker for worm burden ${ }^{2}$ and, on the other hand, it has been identified as the first antibody subclass to decrease after anti-S. mansoni and anti-S. haematobium treatment ${ }^{11,33}$. According to our results, although showing positive levels six months after oxamniquine administration, the determination of $\mathrm{IgG}_{4}$ anti-SEA antibodies could be used as a preliminary test for treatment evaluation in schistosomiasis patients. 
VENDRAME, C.M.V.; CARVALHO, M.D.T.; YAMAMOTO, C.R.F.; NAKHLE, M.C.; CARVALHO, S.A. \& CHIEFFI, P.P. - Evaluation of anti-Schistosoma mansoni IgG antibodies in patients with chronic schistosomiasis mansoni before and after specific treatment. Rev. Inst. Med. trop. S. Paulo, 43(3):153-159, 2001.

Analysis of IgG anti-AWA and anti-SEA immunoblottings showed a heterogeneous pattern before and after specific treatment in the 17 patients studied. The bands of 31-32 kDa, considered to be of high diagnostic value $17,35,36,37$, were found in $82 \%$ and $53 \%$ of cases, respectively, before treatment when AWA and SEA were analyzed (Tables 2 and 3). This kind of diversity was, in fact, previously pointed out by others in Brazilian schistosomiasis patients: VALLI et al. ${ }^{43}$ found $98 \%$ positivity for the $31 \mathrm{kDa}$ band and KIMURA ${ }^{22}$ found only $12.5 \%$ positivity for the same strand.

Although the 31-32 kDa bands have been considered as good markers for schistosomiasis cure after specific treatment by some researchers ${ }^{23,38}$, in the evaluation performed 180 days after oxamniquine administration these bands vanished in only three cases (Tables 2 and 3), persisting in $65 \%$ and $29 \%$ of the patients studied when AWA and SEA antigens were used, respectively (Table 4).

In summary, the use of COPT, immunoenzymatic tests as well as the immunoblotting techniques did not permit a safe and definitive early evaluation of schistosomiasis treatment in the 17 patients studied. Thus, the ideal diagnostic method for schistosomiasis cure control seems to be still far from available, but $\mathrm{IgG}_{4}$ subclass levels showed a significant decrease up to 180 days after specific treatment. Long term post treatment follow-up would be relevant and other studies are necessary to define in further detail the role of $\mathrm{IgG}_{4}$ and its promising usefulness as a possible cure marker.

\section{RESUMO}

\section{Avaliação da presença de anticorpos IgG anti-Schistosoma mansoni no soro de pacientes com esquistossomose mansônica crônica, antes e após tratamento específico}

Em 17 pacientes com infecção crônica por Schistosoma mansoni utilizaram-se os testes de reação periovular, imunoenzimático (ELISA) e imunoblotting, empregando-se antígenos obtidos a partir de vermes adultos (AWA) ou de ovos de S. mansoni (SEA), para detecção de anticorpos antiS. mansoni, antes e em quatro ocasiões após tratamento com oxamniquine. Quando cotejados a grupo controle os pacientes esquistossomóticos revelaram altos níveis séricos de anticorpos IgG nos testes ELISA (antiAWA e anti-SEA), não se observando, porém, negativação até seis meses após tratamento específico. Encontrou-se, entretanto, decréscimo significativo, sem negativação, dos níveis de $\mathrm{IgG}_{1}, \mathrm{IgG}_{3}$ e, principalmente, $\mathrm{IgG}_{4}$, quando se utilizou antígeno solúvel obtido a partir de ovos de $S$. mansoni (SEA), seis meses após administração de oxamniquine. O mesmo não foi observado no caso de anticorpos da subclasse $\mathrm{IgG}_{2}$.

Nos imunoblottings efetuados com o emprego de antígeno de verme adulto (AWA), antes do tratamento com oxamniquine, evidenciou-se a presença de banda com $31 \mathrm{kDa}$ em $14(82 \%)$ dos 17 pacientes estudados, observando-se seu desaparecimento em três pacientes examinados seis meses após tratamento específico. Quando se utilizou antígeno obtido a partir de ovos de S. mansoni (SEA) a mesma banda foi evidenciada em nove pacientes, desaparecendo em quatro casos, após o tratamento.

\section{REFERENCES}

1. BOROS, D.L. \& WARREN, K.S. - Delayed hypersensitivity-type granuloma formation and dermal reaction induced and elicited by a soluble factor isolated from Schistosoma mansoni eggs. J. exp. Med., 132: 488-507, 1970.
2. BOCTOR, F.N. \& PETER, J.B. - IgG subclasses in human chronic schistosomiasis: over-production of schistosome-specific and non-specific IgG4. Clin. exp. Immunol., 82: $574-578,1990$.

3. CHIEFFI, P.P.; MARQUES, R.M. \& SIQUEIRA, J.G.V. - Avaliação da eficácia do método de Kato-Katz no diagnóstico parasitológico da esquistossomose mansônica. Rev. Inst. Adolfo Lutz, 41: 23-30, 1981.

4. DOENHOFF, M.J.; DUNNE, D.W. \& LILLYWHITE, J.E. - Serology of Schistosoma mansoni infection after chemoterapy. Trans. roy. Soc. trop. Med. Hyg., 83: 237238, 1989.

5. DUNNE, D.W.; LUCAS, S.; BICKLE, Q. et al. - Identification and partial purification of an antigen $\left(\omega_{1}\right)$ from Schistosoma mansoni eggs which is putatively hepatotoxic in T cell deprived mice. Trans. roy. Soc. trop. Med. Hyg., 75: 54-71, 1981.

6. DUNNE, D.W.; HILLYER, G.V. \& VAZQUEZ, G. - Schistosoma mansoni cationic egg antigens (CEF-6): immunoserology with oxamniquine-treated patients and involvement of CEF-6 in the circumoval precipitin reaction. Amer. J. trop. Med. Hyg., 38: 508-514, 1988.

7. DUNNE, D.W.; JONES, F.M. \& DOENHOFF, M.J. - The purification, characterization, serological activity and hepatotoxic properties of two cationic glycoproteins ( $\alpha_{1}$ and $\omega_{1}$ ) from Schistosoma mansoni eggs. Parasitology, 103: 225-236, 1991.

8. ENGELS, D; SINZINKAYO, E. \& GRYSEELS, B. - Day-to-day egg count fluctuation in Schistosoma mansoni infection and its operational implications. Amer. J. trop. Med. Hyg., 54: 319-324, 1996.

9. FELDMEIER, H. \& POGGENSEE, G. - Diagnostic techniques in schistosomiasis control. A review. Acta trop. (Basel), 52: 205-220, 1993.

10. GAZZINELLI, G.; LAMBERTUCCI, J.R.; KATZ, N. et al. - Immune responses during human schistosomiasis mansoni. XI. Immunologic status of patients with acute infections and after treatment. J. Immunol., 135: 2121-2127, 1985.

11. GROGAN, J.L.; KREMSNER, P.G.; VAN DAM, G.J. et al. - Antischistosome IgG4 and IgE responses are affected differentially by chemotherapy in children versus adults. J. infect. Dis., 173: 1242-1247, 1996.

12. HASSAN, M.M.; BADAWI, M.A. \& STRAND, M. - Circulating schistosomal antigen in diagnosis and assessment of cure in individuals infected with Schistosoma mansoni. Amer. J. trop. Med. Hyg., 46: 737-744, 1992.

13. HILLYER, G.V. \& GOMEZ DE RIOS, I. - The enzyme-linked immunosorbent assay (ELISA) for the immunodiagnosis of schistosomiasis. Amer. J. trop. Med. Hyg., 28: $237-241,1979$.

14. HILLYER, G.V.; RUIZ-TIBEN, E.; KNIGHT, W.B.; GOMEZ de RIOS, I. \& PELLEY, R.P. - Immunodiagnosis of infection with Schistosoma mansoni: comparison of ELISA, radioimmunoassay, and precipitation tests performed with antigens from eggs. Amer. J. trop. Med. Hyg., 28: 661-669, 1979.

15. HILLYER, G.V.; NIEVES-FRAU, L.F. \& VAZQUEZ, G. - Identification of a genusspecific Schistosoma mansoni soluble egg antigen reactive with the serum of infected patients. Amer. J. trop. Med. Hyg., 35: 1198-1204, 1986.

16. HILLYER, G.V \& GALANES, M.S. - Seroepidemiology of schistosomiasis in Puerto Rico: evidence for vanishing endemicity. Amer. J. trop. Med. Hyg., 60: 827-830, 1999.

17. IDRIS, M.A. \& RUPPEL, A. - Diagnostic Mr 31/32,000 Schistosoma mansoni proteins (SM31/32): reactions with sera from Sudanese patients infected with $S$. mansoni or S. haematobium. J. Helminth., 62: 95-101, 1988.

18. ISKANDER, R.; DAS, P.K. \& AALBERSE, R.C. - IgG4 antibodies in Egyptian patients with schistosomiasis. Int. Arch. Allergy, 66: 200-207, 1981.

19. JASSIN, A.; HASSAN, K. \& CATTY, D. - Antibody isotypes in human schistosomiasis mansoni. Paras. Immunol., 9: 627-650, 1987. 


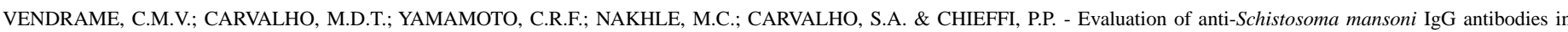
patients with chronic schistosomiasis mansoni before and after specific treatment. Rev. Inst. Med. trop. S. Paulo, 43(3):153-159, 2001.

20. KANAMURA, H.Y.; DIAS, L.C.S.; DA SILVA, R.M. et al. - A comparative epidemiologic study of specific antibodies (IgM and IgA) and parasitological findings in an endemic area of low transmission of Schistosoma mansoni. Rev. Inst. Med. trop. S. Paulo, 40: $85-91,1998$

21. KATZ, N.; CHAVES, A. \& PELlEGRINO, J. - A simple device for quantitative stool thick-smear technique in schistosomiasis mansoni. Rev. Inst. Med. trop. S. Paulo, 14: $397-400,1972$.

22. KIMURA, E.A.S. - S. mansoni: análise por "western-blot” dos antígenos envolvidos na resposta humoral de pacientes submetidos ao tratamento. São Paulo, 1986. [Master's Thesis - Instituto de Ciências Biomédicas da Universidade de São Paulo].

23. KLINKERT, M.Q.; BOMMERT, K.; MOSER, D. et al. - Immunological analysis of cloned Schistosoma mansoni antigens Sm31 and Sm32 with sera of schistosomiasis patients. Trop. Med. Parasit., 42: 319-324, 1991.

24. LAEMMLI, U.K. - Cleavage of structural proteins during the assembly of the head of bacteriophage T4. Nature (Lond.), 227: 680-685, 1970.

25. LOWRY, O.H.; ROSEBROUGH, N.J.; FARR, A.L. \& RANDALL, R.J. - Protein measurement with the folin phenol reagent. J. biol. Chem., 193: 265-275, 1951.

26. McLAREN, M.L.; LONG, E.G.; GOODGAME, R.W. \& LILLYWHITE, J.E. Application of the enzyme-linked immunosorbent assay (ELISA) for the serodiagnosis of Schistosoma mansoni infections in St. Lucia. Trans. roy. Soc. trop. Med. Hyg., 73: 636-639, 1979.

27. McLAREN, M.L.; LILlYWHite, J.E.; DUNNE, D.W. \& DOENHOFF, M.J. Serodiagnosis of human Schistosoma mansoni infections: enhanced sensitivity and specificity in ELISA using a fraction containing S. mansoni egg antigens $\omega_{1}$ and $\alpha_{1}$. Trans. roy. Soc. trop. Med. Hyg., 75: 72-79, 1981.

28. MOTT, K.E. \& DIXON, H. - Collaborative study on antigens for immunodiagnosis of schistosomiasis. Bull. Wld. HIth. Org., 60: 729-753, 1982.

29. NASH, T.E. - Schistosomiasis and other trematode infections. In: ISSELBACKER, K.J. et al., ed. Harrison's principles of internal Medicine. 13. ed. New York, Mc Graw Hill International, 1994. pt. 6, p. 924-931.

30. NOYA, O.; LOSADA, S.; ALARCÓN DE NOYA, B. et al. - Effect of chemotherapy on immune response to egg antigens of Schistosoma mansoni in chronically infected children from areas of low transmission. Paras. Immunol., 17: 111-117, 1995.

31. OLIVER-GONZÁLEZ, J. - Anti-egg precipitins in sera of humans infected with Schistosoma mansoni. J. infect. Dis., 95: 86-91, 1954.

32. PASSOS, A.D.C. \& AMARAL, R.S. - Esquistossomose mansônica: aspectos epidemiológicos e de controle. Rev. Soc. bras. Med. trop., 31(supl. 2): 61-74, 1998.
33. RAMÍREZ, R.M.; CEBALLOS, E.; ALARCÓN DE NOYA, B.; NOYA, O. \& BIANCO, N. - The immunopathology of human schistosomiasis. III. Immunoglobulin isotype profiles and response to praziquantel. Mem. Inst. Oswaldo Cruz, 91: 593-599, 1996.

34. ROBERTS, S.M.; WILSON, R.A.; OUMA, J.H. et al. - Immunity after treatment of human schistosomiasis mansoni: quantitative and qualitative antibody responses to tegumental membrane antigens prepared from adult worms. Trans. roy. Soc. trop. Med. Hyg., 81: 786-793, 1987.

35. RUPPEL, A.; DIESFELD, H.J. \& ROTHER, U. - Immunoblot analysis of Schistosoma mansoni antigens with sera of schistosomiasis patients: diagnostic potential of an adult schistosome polypeptide. Clin. exp. Immunol., 62: 499-506, 1985.

36. RUPPEL, A.; SHI, Y.E.; WEI, D.X. \& DIESFELD, H.J. - Sera of Schistosoma japonicuminfected patients cross-react with diagnostic $31 / 32 \mathrm{kD}$ proteins of $S$. mansoni. Clin. exp. Immunol., 69: 291-298, 1987.

37. RUPPEL, A.; IDRIS, M.A.; SULAIMAN, S.M. \& HILALI, A.M.H. - Schistosoma mansoni diagnostic antigens (Sm31/32): a sero-epidemiological study in the Sudan. Trop. Med. Parasit., 41: 127-130, 1990.

38. RUPPEL, A.; XING, Y.; DELL, R.; NUMRICH, P. \& SHI, Y.E. - Schistosoma mansoni and S. japonicum: decline of antibodies against diagnostic adult worm antigens (Sm31/32) following praziquantel treatment of mice. Trop. Med. Parasit., 42: 325-331, 1991.

39. SILVA, L.C. da: HOSHINO-SHIMIZU, S.; KANAMURA, H. et al. - Serum antibody changes after chemotherapy of patients with schistosomiasis mansoni. A statistical analysis. Rev. Inst. Med. trop. S. Paulo, 17: 344-349, 1975.

40. SPENCER, L.; DE NOYA, B.A.; NOYA, O. \& MASROUA, G. - Análisis comparativo entre la prueba de precipitación circumoval y ELISA con antígenos crudos para el diagnóstico de la esquistosomiasis en Venezuela. G.E.N. (Caracas), 45: 77-83, 1991.

41. SOBH, M.A.; MOUSTAFA, F.E.; HAMED, S.M. \& GHONEIM, M.A. - Infectious glomerulopathy induced by a defined agent (Schistosoma mansoni): progression despite early elimination of the causal agent. Exp. Nephrol., 1: 261-264, 1993.

42. TANABE, M.; OKAZAKI, M.; OKAZAKI, M. et al. - Serological studies on schistosomiasis mansoni in the Northeast Brazil (I). Rev. Inst. Med. Trop. S. Paulo, 32: 121-131, 1990.

43. VALLI, L.C.; KANAMURA, H.Y.; DA SILVA, R.M.; RIBEIRO-RODRIGUES, R. \& DIETZE, R. - Schistosomiasis mansoni: immunoblot analysis to diagnose and differentiate recent and chronic infection. Amer. J. trop. Med. Hyg., 61: 302-307, 1999.

44. WORLD HEALTH ORGANIZATION - The control of schistosomiasis. Wld. Hlth. Org. techn. Rep. Ser., (830), 1993.

Received: 22 December 2000

Accepted: 02 February 2001 